\title{
Estimates Of Intangible Capital In Financial Statements
}

\author{
Martha Sadler Lilly (E-mail: martha.lilly@unco.edu), University of Northern Colorado
}

Ronald O. Reed, University of Northern Colorado

\begin{abstract}
This research implements an inquiry into theoretical financial models and their related applications to intellectual capital (intangible expenditures) in accounting financial statements. Intellectual capital differs from intangible property in that intellectual capital has not yet been documented in the form of patents, copyrights, trademarks, or other specific balance sheet assets (intellectual property). Intellectual capital is indicative of expenditures of a discovery or development nature that has yet to prove its usefulness to the corporation or its marketability to external parties. A random sample of 28 companies was selected from the top Fortune 100 as defined by revenues, using an Internet random number generator. Rather than using earnings to compute capitalization rates, cash flow from operations is used as the surrogate. The rationale is that cash flow is not as easily manipulated as earnings and is not subject to changing accounting rules. Cash flow is critical to corporate survival and so is its funding of development for intangibles. Stock prices are unstable; they even might be categorized as "chaordic." Accounting information provides us with historical cost in a global economy where future inventions and implementations of creative, instantaneous ideas are the foundation for new wealth. Discount rates from four models (capital asset pricing model, weighted average cost of capital, Ibbitson, Black/Isom) are applied to the cash flow from operations stream of the sample firms to determine an estimate of the unrecorded intellectual capital.
\end{abstract}

\section{Introduction}

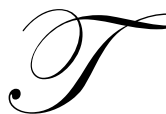

his research implements an inquiry into theoretical financial models and their related applications to intellectual capital (intangible expenditures) in the accounting financial statements. A random sample of 28 companies was selected from the top Fortune 100 (defined by revenues), using an Internet random number generator. Rather than using earnings to compute capitalized values, cash flow from operations (including any associated with intangible amortization) is used as the capitalized value.

We seek to develop the need for the accounting profession to consider the measurement of intellectual capital as a value-added component of a particular company because of alternate methods of accounting treatment to intangible expenditures. Intangible expenditures are capitalized on an entity's balance sheet when purchased from external parties, and certain specified intellectual capital developed in-house may be expensed in accordance with generally accepted accounting principles. Moreover, the implementation of theoretical models on current financial statements of the selected sample is applied to both traditional and technological companies. If there is a relationship of intellectual capital to fair market value, the investor/analyst can identify that relationship. Such information is useful to users (investors and creditors) of a business entity's financial statements. At issue is that financial reporting provides a "rear-view" perspective in a new global economy where future inventions and implementations of creative, instantaneous ideas are the foundation for new wealth.

\section{Purpose}

As the American Institute of Certified Public Accountants (AICPA) endeavors to improve the accountants' image of unethical behavior and the public moves beyond Enron or World.com debacles, it might be wise to look 
at opportunities for the professional accountant to go beyond audit, tax, and compilation/review services. While the professional standards for expensing research and development costs are being reviewed and discussed at the Financial Accounting Standards Board (FASB), a practitioner may forge ahead of the game by evaluating intellectual capital for a number of reasons besides preparation of the balance sheet, income statement, and cash flow statement. Often the Certified Public Accountant (CPA) will act as the financial vice president for a client who is buying or selling intellectual property (documented intellectual capital). A client may have developed advanced software in a minimal amount of time and have no idea of its value so he calls in the CPA for assistance, appraisal, and advice.

The accountant needs to have some idea on how to approximate that value as an additional service to the client. In the event of death, a client may have substantial assets that will pass to designated beneficiaries. The Internal Revenue Service (IRS) is more than happy to assess a value for any portion of an estate, but it may not be a reasonable or favorable one to the heirs. Or, a potential client may purchase a business that incorporates substantial intellectual property; in fact, intellectual property may be the sole asset of real value. The accountant should be sensitive to these opportunities. Thus, the purpose of this research project is to develop a measurement model for intellectual capital as a value-added measurement for evaluating a specific company. This measurement model can assist CPAs in evaluating the value of intangible assets, including intellectual capital.

\section{Background}

Capitalization of expenditures for research and development (R\&D) rests upon a valid measurement of its worth. While historical cost of assets is a major cornerstone of GAAP, fair market value of securities and other assets is now accepted - including recognition of unrealized gains and losses. A further point of consideration is the use of non-financial as well as financial information for analysis of value. Cost management already looks to operational and quality control standards as a means of cost containment and product/service enhancement. Customer satisfaction drives research and development as well as production. The cost versus performance of any product or service is the major variable in what a firm offers the market. Does the customer want it? Will he pay for it? Therefore, if a customer (user of financial statements, in this case) wants full disclosure of intellectual property, the accounting profession ought to investigate ways to measure it.

Accounting and reporting of intangible investments are deficient in corporate financial statements; thus, additional information is needed (Lev, Intangibles, 17). Why is there a deficiency and what are the private and social consequences of failure? Intangibles, in their newness and uniqueness, present special problems. They are high risk, especially in the period between discovery and marketability. The corporate entity lacks full control over the benefits. No markets or exchange process exists, particularly because of their uniqueness and newness. Economic theory predicts, and empirical evidence confirms, that such deficiencies are associated with the following:

- $\quad$ High cost of capital

- $\quad$ Systematic under valuation by investors of shares of intangible intensive companies

- Excessive gains to research and development officers from trading employer stock (insider gains), as in the Enron debacle

- Continued deterioration of usefulness of financial information, with related volatility and excessive riskiness of securities

- $\quad$ Manipulation of financial information through intangibles (Lev, Intangibles, 4)

Intangibles can be defined as assets-a claim to future benefits but without any physical characteristics. Intangibles, knowledge assets, and intellectual capital are used interchangeably by Lev and others in their work; however, once those claims to future benefits are legally secured, as with patents, trademarks, or copyrights, the asset is generally referred to as intellectual property. At that time, accounting rules find it acceptable to designate these items as assets. The areas of intangibles addressed here include discovery of new and innovative technology and organizational practices. Human resources, a third set of intangibles, include training, stock options, and learning opportunities through collaboration with universities and research foundations. These intangibles interact with financial and physical assets to add value to corporate activities. When you have three categories interacting 
with each other, you get a fuzzy image, as opposed to one that is focused, clear, and sharp. A fuzzy image that is relevant, realistic, and accurate is preferable to a clear one--out-of-date, irrelevant, and inaccurate (Kosko, Fuzzy Thinking, 119). It is a relative matter, not an absolute one. Perhaps it's time that accounting rules permit relevant fuzziness, rather than irrelevant precision. Certainly, it is no more fuzzy or illogical to contemplate intangibles and their related value to a corporate structure than to assume that all auditing was completed on December 31 (or the end of the fiscal year) as the audit report states.

The fuzzy property rights or partial excludability of intangible investments creates unique and considerable managerial challenges. The risk of an intangible investment is high, about three times that of physical assets. The reason is because of the time lag in the process of discovery to commercial realization. During that process, information technology may add value to the corporation, add to the gross domestic product, or add wealth through new and better formulas, recipes, or instructions for rearranging things. The reworking of knowledge into a physical form may allow for practical application. Economic and political pressures from the intensified business competition of globalization and deregulation may cause an increase in value.

\subsection{Current Culture}

The corporate infrastructure is efficient and effective through close collaboration with suppliers, customers, and employees made possible by instantaneous communication. These corporate components are closely knitted into a single entity with a bare bones organizational structure. It is more intra-connected than the industrial-age corporations and less dependent upon large numbers of employees. Empirical evidence suggests deficient accounting for intangibles facilitates the release of biased and misrepresented financial reports (Lev, 2001, p. 101).

For example, what are the implications for cost/managerial accounting? It has existed for decades on the input structure of direct material, direct labor, and manufacturing overhead. This system of inputs doesn't predominate anymore; therefore, how can useful financial reporting draw upon this antiquated operating system for good information. Today's system is geared to physical inputs of material and estimated overhead. The lack of direct labor may be the result of intangible expenditures that are lost in the income statement. Intangible inputs are period costs and are never allocated to the product cost. We have lost the product cost. Period costs are a function of the income statement in the period in which they are incurred and lay forever buried within the selling and administrative expenses.

\subsection{Lack Of Existing Markets}

Once intangible assets reach the marketable stage, the risk decreases; however, there are no organized markets for most intangible assets. Intangible costs are run through the income statement in the period incurred and subsequently disappear into the annual report. There is no active, organized market for intangibles. Hopefully, the new web-based Internet markets with many participants and transparent prices will begin to change this particularly risky area. The legal property rights of intangibles are imprecise; and the related contingent contracts, difficult to write. The cost structure of intangibles has large sunk costs up front and negligible marginal costs over its life; this does not give rise to a stable pricing policy.

Some analytical structure may be helpful and appropriate to accountants by investigating the various models. Legalistic models, used in the courtroom for litigation support, include the capital asset pricing model, the weighted-average cost of capital, and the build-up methods of Ibbitson and Black/Isom (Black \& Isom Associates, 1995). These models address the development of discount rates in the capitalization process (CSCPA Litigation Support Conference, 1996). If the legal system accepts these models, they should be acceptable in the financial markets because they are quantifiable and rational. More subjective methodologies include those found in European countries. These models include satisfaction, loyalty, experience, increase in value, quality, customer responsiveness, and the ability to quickly adjust to changing technologies. While these subjective models are very interesting, quantification is an unrealistic goal and an unreasonable expectation. While there is a multitude of ways to measure intellectual property; we want to identify one that is practical and acceptable. 


\section{Measurement Methods}

If we want to use the discounted cash flow model, we need to isolate the cash flow stream that is attributable to the intangible expenditures. The existence of positive cash flow does not necessarily indicate the presence of value; nor does the negative cash flow, the absence of value. Cash flow is an indicator of activity unrelated to accounting rules and regulations. There are at least two ways to separate out the tangible asset cash flow from the total stream. One way is to subtract the amount of cash flow attributable to tangible assets. The percentage of tangible assets times the total cash flow equals the amount attributable to tangible assets. The percentage of financial assets times the total cash flow gives us the cash flow allocation for financial assets. What is left (by default) belongs to intangible assets. Another way is to assign percentages to tangible assets (10.5\%), financial assets (7.0\%), and intangible assets (4.5\%) based on historical data (Lev, 2001).

Once the cash flow attributed to intangible assets can be determined, the discount rate can be applied to produce the expected value of the intangible assets.

\section{Methodologies For Appropriate Discount Rate}

An appropriate rate of return for specific intangible expenditures can be derived. To find the fair market value of economic benefits, we need a discount rate that effectively assesses the risk of the future economic benefits and converts them to a present value. The rationale for using the discounted cash flow method is that it considers the amount of economic benefits, the duration of expected economic benefits, the associated risk, and complementary asset requirements. At least four methods exist for developing capitalization discount rates:

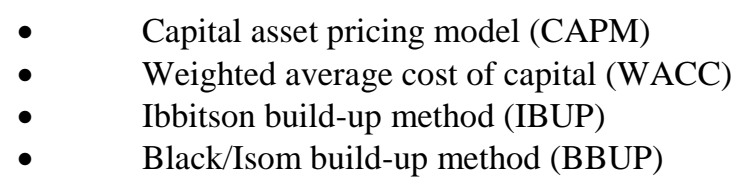

\section{$\underline{\text { CAPM }}$}

The CAPM includes a number of assumptions:

- $\quad$ Investors are risk averse

- $\quad$ Rational investors seek to hold fully diversified portfolios

- $\quad$ All investments have identical holding periods

- $\quad$ There are no transaction costs nor taxes

- Investors expect the same rate of return

The expected return $E\left(r_{i}\right)$ is based on the risk-free rate $\left(R_{f}\right.$ plus the individual beta $(B)$ times the equity risk premium $\left(\mathrm{RP}_{\mathrm{m}}\right)$ for market, size, and/or specific company. In formula form, the CAPM follows:

$E\left(r_{i}\right)=R_{f}+B\left(R P_{m}\right)+R_{s}+R_{u}$

Paper (both color and black/white) copies of the 2001 annual reports of the 28 randomly chosen companies out of the top Fortune 100, ranked by revenues, were utilized in the analysis. We used the risk-free rate of 5.55\% + the beta for each company times the market return (11\%). Size and specific company risks were ignored in this analysis. The Yahoo Finance website "Profile" for each company contained most of the information on the beta, market capitalization, and key financial ratios. In Table 1, we ranked companies according to the CAPM from lowest to highest. The lower the capitalization rate will give the highest values-indicating relatively better share price. 


\begin{tabular}{|c|c|c|c|c|}
\hline \multirow[b]{2}{*}{ Rank } & \multicolumn{4}{|c|}{$\begin{array}{c}\text { Table } 1 \\
\text { Discounts Rates Using CAPM }\end{array}$} \\
\hline & Symbol & Beta & Company & Discount $R$ \\
\hline 31 & MCK & 0.16 & McKesson Corp. & 7.31 \\
\hline 38 & ABS & 0.23 & Albertson's Inc. & 8.08 \\
\hline 93 & CVS & 0.58 & CVS/Pharmacy & 8.48 \\
\hline 24 & MRK & 0.4 & Merck \& Co., Inc. & 9.95 \\
\hline 47 & $\mathrm{JNJ}$ & 0.43 & Johnson \& Johnson & 10.3 \\
\hline 11 & VZ & 0.48 & Verizon Comm. & 10.83 \\
\hline 78 & WAG & 0.51 & Walgreen Co. & 11.11 \\
\hline 95 & SYY & 0.52 & Sysco Corp. & 11.27 \\
\hline 50 & $\mathrm{JCP}$ & 0.54 & J. C. Penney & 11.5 \\
\hline 63 & PBG & -0.06 & Pepsi Bottling Group & 12.15 \\
\hline 55 & UPS & 0.64 & United Parcel Service & 12.59 \\
\hline 32 & S & 0.65 & Sears, Roebuck \& Co. & 12.7 \\
\hline 81 & $\mathrm{P}$ & 0.66 & Phillips Petroleum & 12.81 \\
\hline 65 & INTC & 1.67 & Intel & 12.82 \\
\hline 60 & DOW & 0.74 & Dow & 13.7 \\
\hline 98 & CAT & 0.75 & Caterpillar & 13.8 \\
\hline 75 & $\mathrm{IM}$ & 0.97 & Ingram Micro & 15.12 \\
\hline 84 & UNH & 0.91 & United Health Group & 15.56 \\
\hline 52 & MIR & 0 & Mirant Corp. & 16.5 \\
\hline 8 & CVX & 0 & Chevron/Texaco & 16.55 \\
\hline 15 & $\mathrm{~T}$ & 1.08 & AT\&T Corp. & 17.43 \\
\hline 44 & COST & 1.15 & Costco & 18.2 \\
\hline 40 & KM & 1.2 & Kmart & 18.75 \\
\hline 67 & DPH & 0.65 & Delphi & 18.9 \\
\hline 88 & AA & 1.25 & Alcoa Inc. & 19.3 \\
\hline 71 & GP & 1.37 & Georgia-Pacific Corp. & 21.1 \\
\hline 92 & $\mathrm{CSCO}$ & 1.96 & Cisco Systems & 27.11 \\
\hline 68 & PCS & 2.55 & Sprint PCS Group & 33.55 \\
\hline
\end{tabular}

\section{$\underline{\text { WACC }}$}

If we look to WACC, the weighted cost of capital is equal to the after tax weighted cost of debt $\left(\mathrm{W}_{\mathrm{d}}\right)$ plus the weighted cost of equity $\left(\mathrm{W}_{\mathrm{e}}\right)$. The debt component is the debt percentage $\left(\mathrm{K}_{\mathrm{d}}\right)$ weighted factor times the current or expected interest rate on debt times $\left(1-\right.$ tax rate). The equity component is the equity percentage $\left(\mathrm{K}_{\mathrm{e}}\right)$ weighted factor times the dividends of next year/by stock price now plus the expected growth rate in earnings. Since the CAPM represents an estimate of the cost of equity, that rate is admissible. The market capitalization is acceptable for the equity-weighting factor. In formula format, it reads:

$\mathrm{WACC}=\left(\mathrm{k}_{\mathrm{d}}(1-\mathrm{t}) \mathrm{xW}_{\mathrm{d}}\right)+\left(\mathrm{k}_{\mathrm{e}} \times \mathrm{W}_{\mathrm{e}}\right)$

Annual reports for these same 28 companies were analyzed to determine the book value of the debt and tax structure + equity cost based on the market capitalization. 


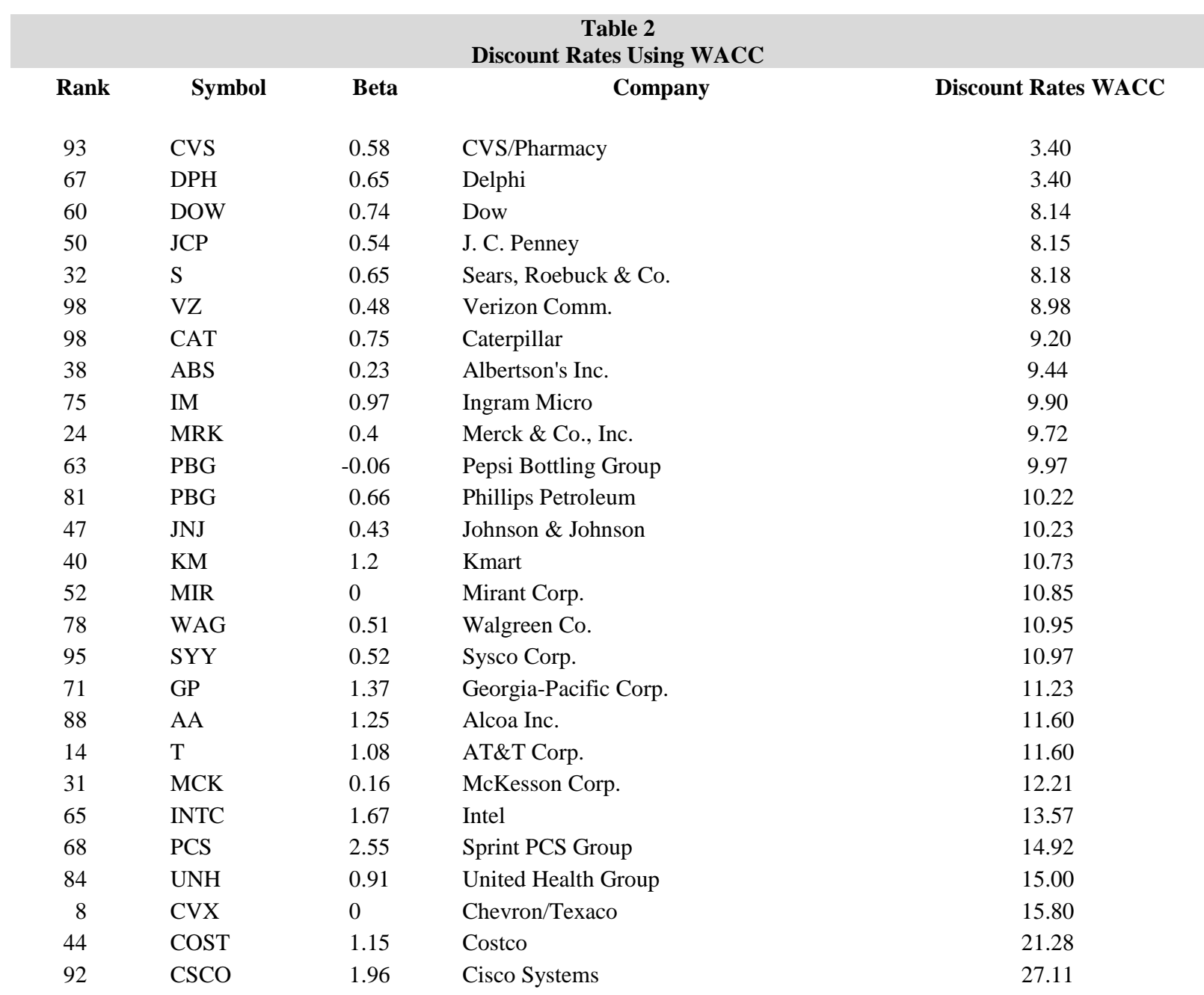

While some corporations moved around or shifted in their rankings, overall company discount rates remain relatively stable, with a few exceptions. The CAPM and the WACC are the more traditional models and offer a foundation for the more subjective methods that follow.

\section{IBUP}

The first build-up method is the well known Ibbitson method. Corporate rankings are closer to those in Table 1, using the CAPM than those found in Table 2 with WACC. The Ibbitson build-up approach is based on several risk factors:

- $\quad$ Safe rate (30 year Treasury Bond)

- $\quad$ Equity risk

- $\quad$ Small company risk

- Industry risk

- $\quad$ Specific company risk 
Subjective risk factors are assigned, using a comparison of industry to specific business. Some risk assessment factors include the following:
- $\quad$ Pre-tax return on equity
- $\quad$ Profitability percentage
- $\quad$ Pre-tax return on assets
- $\quad$ Current ratio
- Industry stability/potential
- $\quad$ Earnings diversity/stability
- $\quad$ Product/service quality
- Location/market position
- Competitiveness/management
- $\quad$ Suppliers/regulations

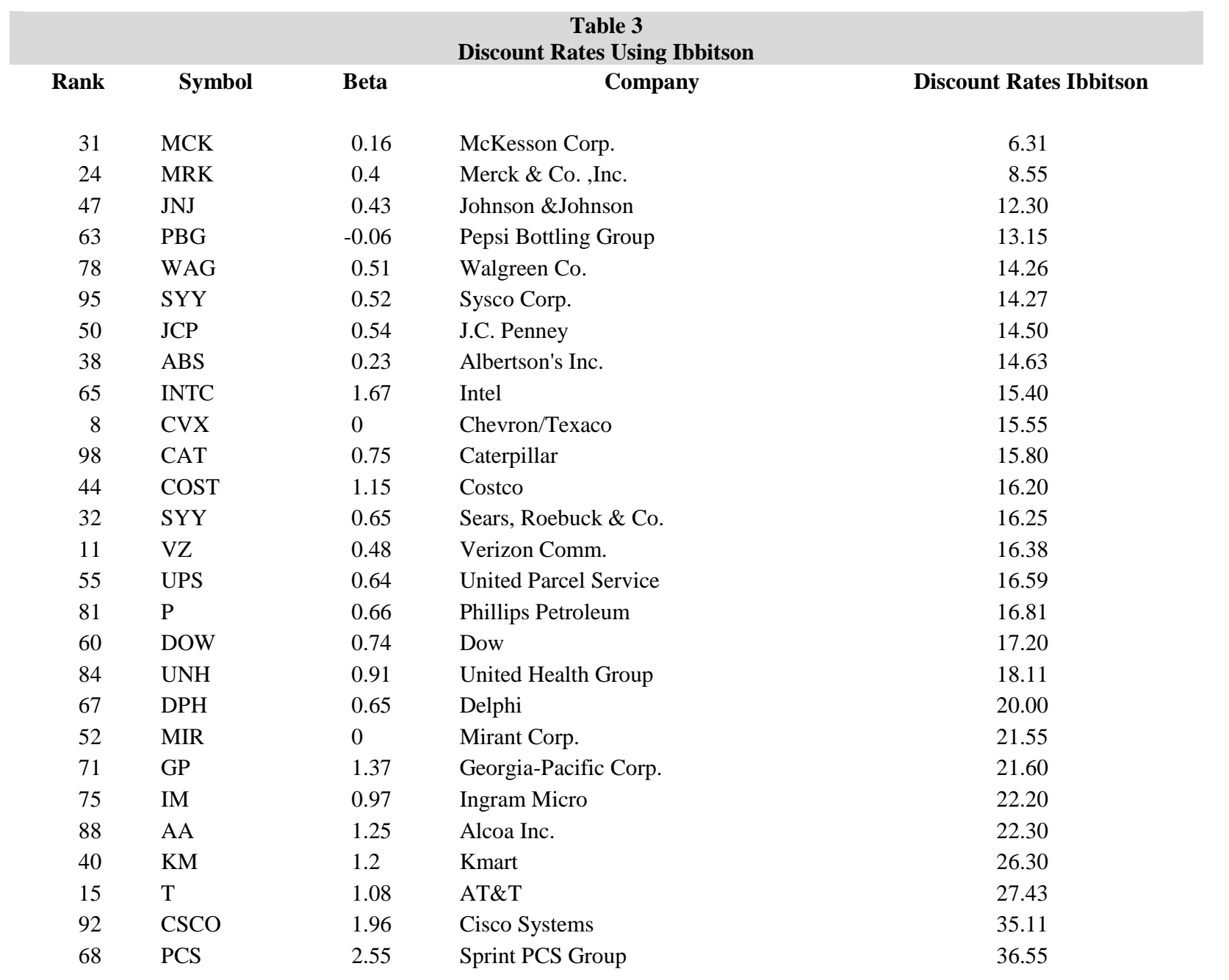


An example of the Ibbitson method follows:

\begin{tabular}{|l|c|}
\hline Risk-free LT government bond rate & $7.0 \%$ \\
\hline Common stock equity risk premium & $7.0 \%$ \\
\hline Small stock equity risk premium & $5.1 \%$ \\
\hline Subjective risk premium & $\underline{6.0 \%}$ \\
\hline = Discount rate & $25.1 \%$ \\
\hline less: LT business growth rate & $\underline{(5.0 \%)}$ \\
\hline & \\
\hline & $\underline{\underline{20.1 \%}}$ \\
\hline
\end{tabular}

Table 3 shows the discount rates for the 28 companies using the IBUP method.

\section{$\underline{\text { BBUP }}$}

The Black/Isom build-up approach includes the following variables:

- $\quad$ Competition

- $\quad$ Financial strength

- $\quad$ Management ability and depth

- $\quad$ Profitability

- $\quad$ National economic effects

- Local economic effects

- $\quad$ Local economic effects

The Black/Isom model uses a similar approach to Ibbitson by assigning weights to the various factors. The first four are considered to be risk factors and they are weighted on a five point scale from high to low $(10-2)$. Economic conditions are categorized as weak, no effect, or strong. National conditions would carry a +1 for weak to -1 for strong local conditions would carry a weighting factor of $+/--2$. Financial strength is based upon five traditional variables:

- $\quad$ Total debt to assets

- $\quad$ Long term debt to equity

- $\quad$ Current ratio

- $\quad$ Quick ratio

- Interest coverage

Profitability and stability of earnings are based upon five other traditional variables:

- $\quad$ Years in business

- Industry life cycle

- $\quad$ Return on sales

- $\quad$ Return on assets

- $\quad$ Return on equity

Table 4 reflects the discount rate for the 28 companies using the BBUP method. The ranking of Tables 3 and 4 are quite similar. BBUP seems to be more amenable to the legal profession; less information is available in the general business (or accounting) literature. 


\begin{tabular}{|c|c|c|c|c|}
\hline \multicolumn{5}{|c|}{$\begin{array}{c}\text { Table } 4 \\
\text { Discount Rates Using Blk/Isom }\end{array}$} \\
\hline Rank & Symbol & Beta & Company & Discount Rates Blk/Isom \\
\hline 31 & MCK & 0.16 & McKesson Corp. & 8.0 \\
\hline 24 & MRK & 0.4 & Merck \& Co., Inc. & 9.0 \\
\hline 63 & PBG & -0.06 & Pepsi Bottling Group & 9.0 \\
\hline 47 & JNJ & 0.43 & Johnson \& Johnson & 10.0 \\
\hline 38 & $\mathrm{ABS}$ & 0.23 & Albertson's Inc. & 10.0 \\
\hline 98 & CAT & 0.75 & Caterpillar & 11.0 \\
\hline 65 & INTC & 1.67 & Intel & 12.0 \\
\hline 93 & CVS & 0.58 & CVS/Pharmacy & 13.5 \\
\hline 78 & WAG & 0.51 & Walgreen Co. & 13.5 \\
\hline 15 & $\mathrm{~T}$ & 1.08 & AT\&T Corp. & 14.0 \\
\hline 81 & $\mathrm{P}$ & 0.66 & Phillips Petroleum & 14.0 \\
\hline 32 & S & 0.65 & Sears, Roebuck \& Co. & 14.0 \\
\hline 55 & UPS & 0.64 & United Parcel Service & 14.0 \\
\hline 8 & CVX & 0 & Chevron/Texaco & 15.0 \\
\hline 60 & DOW & 0.74 & Dow & 15.0 \\
\hline 95 & SYY & 0.52 & Sysco Corp. & 16.0 \\
\hline 92 & $\mathrm{CSCO}$ & 1.96 & Cisco Systems & 17.0 \\
\hline 50 & $\mathrm{JCP}$ & 0.54 & J. C. Penney & 17.0 \\
\hline 44 & COST & 1.15 & Costco & 18.0 \\
\hline 84 & UNH & 0.91 & United Health Group & 18.0 \\
\hline 88 & AAD & 1.24 & Alcoa Inc. & 19.5 \\
\hline 52 & MIR & 0 & Mirant Corp. & 20.0 \\
\hline 11 & $\mathrm{VZ}$ & 0.48 & Verizon Comm. & 20.0 \\
\hline 68 & PCS & 2.55 & Sprint PCS Group & 20.5 \\
\hline 67 & $\mathrm{DPH}$ & 0.65 & Delphi & 22.0 \\
\hline 71 & GP & 1.37 & Georgia-Pacific Corp. & 22.0 \\
\hline 75 & $\mathrm{IM}$ & 0.97 & Ingram Micro & 23.0 \\
\hline 40 & KM & 1.2 & Kmart & 27.0 \\
\hline
\end{tabular}

\subsection{Pitfalls}

Common errors to avoid in developing rates include indiscriminate use of the price/earnings method (size, structure, capitalization) or using rates from the wrong period. Applying rates on safe investments to business valuations (a risky investment) is an error to be avoided. Other errors found are inadequate documentations, historical rates for the required rate of return, reliance on the rule of thumb, and failure to match rates with earnings.

Intangible expenditures are independent of financial structures and should be studied as such. Isolating the stream of cash flows for intangibles is key to compensating companies that enter into risk taking ventures. Cash flow derived from intangible expenditures must be an amount that will yield a fair rate of return over the term of the investment in the intangible project, as well as the complementary tangible and financial assets. A fair return must first be allocated to physical and financial assets and must address two important factors: 
- $\quad$ Absolute amounts of each asset category (intangible, tangible, and financial)

- $\quad$ Appropriate rate of return to associate with each

Rates of return on financial assets may use the rate on 90-day certificate of deposits or money market funds as a benchmark. A rate of $4.5 \%$ has been used for financial assets (Lev, 2001). Tangible assets can be pegged at the interest rate at which commercial banks make loans, using the fixed assets as collateral or $7 \%$.

Using relative percentage amounts (as opposed to absolute amounts) is circular reasoning and provides no information. According to Lev, using fair market value - book value $=$ intangibles value is useless information and is therefore rejected. While the legalistic (IBUP, BBUP) approach is useful in a court of law, a more rationale case can be made for the accounting/financial approach that uses the same discount rates for each company, differenttiating that rate according to the type of property is involved. Finding the proportionate share of each of the three types of property within a company and then making attributions of free cash flow to those types of property provides a clean distribution of cash flow. Cash flow has been used because of the unusual nature of the economy at this time. Many companies are showing losses, frequently because of booking some accounting pronouncement that has nothing to do with cash flows. Restructuring charges, goodwill/intangible amortizations, impairment of intangible or tangible property as opposed to amortization/depreciation makes up considerable charges against the earnings of an entity.

\subsection{An Illustration To Estimate The Intangible Value}

Using the preceding four methods to determine discount rates, Table 5 demonstrates how estimates for the intangible capital for two companies, Sears and CVS/pharmacy, can be determined.

In viewing the information in Table 5, estimate for the intangible class of assets depends upon the discount method used. One finds the lower the discount rate, the higher the estimate of the value for intangible capital. Thus, the unrecorded investment in intangible capital offers good value when the debt structure is under control and the company has a low WACC. The more subjective discount rates Ibbitson and Black/Isom offer far more flexibility in coming up with a value, such as might be desired in a court or legal battle.

\section{Results}

Companies with the highest capitalization rates appear to offer the least value for intangible assets. The highest discount rates are found in the telecommunications industry. Their debt structure is on overload. Other companies with higher capitalization rates are in or are close to bankruptcy. Pharmaceutical companies appear to be the premier value companies because of lowest capitalization rates. Based on a target market geared towards an aging population, prescription drugs can only continue to grow. Sears, the preferred retailer of the masses, is wedged comfortably in to the middle with little opportunity for faltering (Consumer Reports, 2002).

\section{Implications For Further Research}

While the FASB reviews and discusses various treatments of intellectual capital, we know that expertise, creativity, and intellect have value. Our clientele and the marketplace know that. The CPA must become familiar with evaluating these types of intangibles. The discounted cash flow method is one way. At the very least, it may be appropriate at this time to include intellectual capital in the "Notes to Financial Statements" or some other form of disclosure for the user. To ignore or simply expense the value of intellectual property is highly questionable.

As the free world market continues to develop into more creative and instantaneous dimensions, the need for valuation methods of intangible assets, both subjective and objective, will continue. An analysis of any Fortune 500 company would lend itself to a review of these different methods. Refinement of the discounted cash flow method, market value based on stock price, historical cost, or subjective reviews based on the development of a matrix would be a help to the profession. Implementation of these methods can assist the accountant in developing future work. If the accountants do not address these issues, the management consultant, lawyers, and courts will. 


\section{Examples For Determining Intangible Capital Estimate}

\begin{tabular}{|c|c|c|c|c|}
\hline & & \multicolumn{2}{|c|}{ Asset Class (in millions) } \\
\hline & & & Tangible & Financial \\
\hline & & & Assets & Assets \\
\hline \multicolumn{5}{|c|}{ Sears, Roebuck \& Co Balance Sheet } \\
\hline \multicolumn{2}{|c|}{ Classification } & & $\$ 6,824$ & $\$ 1,064$ \\
\hline \multicolumn{3}{|c|}{ Return attributable to this class } & $\underline{X \quad .07}$ & $\underline{X .045}$ \\
\hline \multicolumn{3}{|c|}{ Cash flow from tangible and financial assets } & $\$ 477.68$ & $\$ 47.88$ \\
\hline \multicolumn{2}{|c|}{ Total cash flow from operations } & $\$ 2,262$ & & \\
\hline \multicolumn{2}{|c|}{ less CF from tangible assets } & -477.68 & & \\
\hline \multicolumn{2}{|c|}{ less CF from financial assets } & $\underline{-47.88}$ & & \\
\hline \multirow{2}{*}{\multicolumn{2}{|c|}{ Residual assigned to Intangible Assets }} & $\$ 1,736.44$ & & \\
\hline & & Intangible Capital & 1 Estimate & \\
\hline CAPM & $12.70 \%$ & $\$ 13,672.76$ & & \\
\hline WACC & $8.18 \%$ & $21,227.87$ & & \\
\hline IBUP & $16.25 \%$ & $10,685.78$ & & \\
\hline \multirow[t]{4}{*}{ BBUP } & $14 \%$ & $12,403.14$ & & \\
\hline & & & \multicolumn{2}{|c|}{$\underline{\text { Asset Class (in millions) }}$} \\
\hline & & & Tangible & Financial \\
\hline & & & Assets & Assets \\
\hline \multicolumn{2}{|l|}{ CVS/pharmacy } & & $\$ 5,765.90$ & $\$ 1,202.50$ \\
\hline \multicolumn{2}{|c|}{ Return attributable to this class } & & $\begin{array}{ll}\mathrm{X} & .07 \\
\end{array}$ & X .045 \\
\hline \multicolumn{2}{|c|}{ Cash flow from tangible and financial assets } & & $\$ 403.60$ & $\$ 54.11$ \\
\hline \multicolumn{2}{|c|}{ Total cash flow from operations } & $\$ 1,003.19$ & & \\
\hline \multicolumn{2}{|c|}{ less CF from tangible assets } & -403.6 & & \\
\hline \multicolumn{2}{|c|}{ less CF from financial assets } & $\underline{-54.11}$ & & \\
\hline \multirow{2}{*}{\multicolumn{2}{|c|}{ Residual assigned to Intangible Assets }} & $\$ 545.48$ & & \\
\hline & & Intangible Capital & & \\
\hline CAPM & $8.48 \%$ & $\$ 6,432.55$ & & \\
\hline WACC & $3.40 \%$ & $16,043.53$ & & \\
\hline IBUP & $14.00 \%$ & $3,896.29$ & & \\
\hline BBUP & $13.50 \%$ & $4,040.59$ & & \\
\hline
\end{tabular}




\section{Bibliography}

1. Abdolmohammadi, Mohammad J., L. Greenlay, Bentley College, D. Poole, The Cambridge Institute for Applied Research. "Accounting Methods for Measuring Intellectual Capital", http://www.roundtablegroup.com/scholars/articles/acctg-intellectual-capital.html. 2.

2. Annin, Michael, CFA. "Ibbotson Research: Using Ibbotson Associates' Data to Develop Minority Discount Rates", http://www.ibbotson.com/research/papers/Data_Minority/default.asp. 2.

3. Annin, Michael, CFA and D. Falaschetti, CFA. "Ibbotson Research: Is There Still a Size Premium?" “CPA Expert, 1998." http://www.ibbotson.com/Research/papers/Size_Premium/default.asp. 1.

4. Bassi, Laurie J. and M Van Buren. "Valuing Investments in Intellectual Capital", International Journal of Technology Management, Vol. 18, Nos. 5/6/7/8, 1999. 414 - 431.

5. http://www.best_in_class.com/research/bestpracticespotlights/intellectual_capital_20.htm.

6. Bontis, Nick. "What is your knowledge worth?" http://www.business.mcmaster.ca/mktg/nbontis/ic/. 15.

7. Brinker, Barry, CPA. "Intellectual Capital: Tomorrow's Asset, Today's Challenge." http://www.cpavision.org/vision/wpaper05b.cfm. 12.

8. Davies, Jan, and A. Waddington. "The management and measurement of intellectual capital." Management accounting. Vol. 77, no. 8. September/1999. 34.

9. Johnson, William H. A. "An integrative taxonomy of intellectual capital: measuring the stock and flow of intellectual capital components in the firm. Int. J. Technology Management, Vol. 18, Nos. 5/6/7/8, 1999.

10. Kaplan, Paul D., J. Peterson. "Ibbotson Research: Full-Information Industry Betas." http://www.ibbotson.com/research/papers/Industry_Betas/default.asp. 1.

11. Kosko, Bart. Fuzzy Thinking. First Edition. 1993. New York, New York: Hyperion.

12. Lev, Baruch. Intangibles: Management, Measurement, and Reporting. First Edition. 2001. Washington, D.C. Brookings Institution.

13. Lynn, B. E., "Culture and intellectual capital management: a key factor in successful ICM Implementation." International Journal of Technology Management. Vol. 18, Nos. 5/6/7/8, 1999. 590603.

14. Lynn, Bernadette. "Intellectual Capital Key to Value Added Success." Chartered Accountants Journal. April 2000. 24-31.

15. Moore, Cathleen. "Tapping knowledge." InfoWorld. October 12, 2001. 2.

16. Rastogi, P. N. "Knowledge management and intellectual capital-the new virtuous reality of competitiveness." Human Systems Management 19 (2000) 39-48.

17. Reed, Ronald O., John Elsea., M. Lilly. "Accounting for Excess Purchase Price: Goodwill or expense? Instructional issues.” Journal of Education for Business. November/December 2000. 87-92.

18. Scheffman, David and W. Robert Thompson. "Bright Ideas, Big Money, Part I." http://www.round.table.com/rtg/scholars/articles/bright-ideasl.html. Vanderbilt University.

19. Ibid. Part II: "Intellectual Capital in Your Company."

20. Stewart, Thomas A. “Accounting gets radical.” Fortune. April 16, 2000. pp. 184-192, 194.

21. The Wealth of Knowledge. First Edition. 2001. New York, New York: Random House.

22. Sveiby, Karl-Erik. "Intellectual Capital - thinking ahead." Australian CPA. June 1998. http://www.cpaonline.com/au/html/aa/9806/pgaa9806_intellectu.html. 4.

23. "Where to Buy." Consumer Reports. Volume 67, No. 7. July, 2002. 11-15. 